\title{
PHYSICAL EXERCISE AFTER IMMOBILIZATION OF SKELETAL MUSCLE OF ADULT AND AGED RATS
}

\author{
EXERCICIO FÍSICO APÓS IMOBILIZAÇÃO DE MÚSCULO ESQUELÉTICO DE RATOS ADULTOS E IDOSOS
}

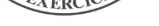

EJERCICIO FISICO DESPUÉSDE LA INMOVILIZACIÓN DEL MÚSCULO ESQUELÉTICO DERATAS

Original Article ARTIGO ORIGINAL ADULTAS Y MAYORES

\author{
Tatiana Emy Koike \\ (Physiotherapist) \\ Adriana Yukie Watanabe \\ (Physiotherapist) \\ Fábio Yoshikazu Kodama' \\ (Physiotherapist) \\ Guilherme Akio Tamura Ozaki ${ }^{2}$ \\ (Physiotherapist) \\ Robson Chacon Castoldi ${ }^{2}$ \\ (Physical Education Professional) \\ Thiago Alves Garcia' \\ (Physiotherapist) \\ Regina Celi Trindade Camargo' \\ (Physiotherapist) \\ José Carlos Silva Camargo Filho \\ (Physiotherapist)

\begin{abstract}
1. Universidade Estadual de São Paulo "Julio de Mesquita Filho", Faculdade de Ciência e Tecnologia, Presidente Prudente, SP, Brazil. 2. Universidade de Campinas, Faculdade de Ciências Médicas, Campinas, SP, Brazil.
\end{abstract}

\section{Correspondence:}

Rua Roberto Simonsen, 305, Presidente Prudente, São Paulo, SP. 19060-900.

tatiemykoike@gmail.com

\begin{abstract}
Introduction: Immobilization is a treatment technique often used to reduce pain and prevent worsening of the injury. However, it promotes harmful effects on musculoskeletal tissue, resulting in a marked loss of muscle function, which may be aggravated in the elderly. Physical exercise is an important intervention to mitigate these harmful effects. Objective:To analyze possible morphometric changes in the gastrocnemius muscle of rats after immobilization and remobilization with physical exercise. Methods: Fifty-six rats were divided into adult (A) and aged (E) groups and subdivided into adult and aged control (AC and EC), immobilized (Al and El), free remobilized (AIF and EIF), and remobilized through physical exercise (AIE and EIE). The hind limbs were immobilized with the gastrocnemius muscle in a shortened position for a period of seven days, except for the control group. The exercise protocol consisted of five swimming sessions, once per day (25 minutes/ session). The animals were euthanized by administration of an overdose of ketamine hydrochloride plus xylazine hydrochloride, followed by sample collection and preparation of hematoxylin and eosin slides. Measurements of the smallest diameter of 120 muscle fibers of each animal were taken with software NIS-Elements D3.0 - SP7 - Nikon ${ }^{\circledR}$ instruments Inc., $N Y$, USA. Results: There was a significant reduction in the mean fiber diameter in the $\mathrm{Al}(38.43 \mu \mathrm{m} \pm 4.20 ; \mathrm{p}=0.01)$ and AIF $(36.97 \mu \mathrm{m} \pm 3.41 ; p<0.01)$ groups compared to $\mathrm{AC}(45.39 \mu \mathrm{m} \pm 3.41)$ and in the El $(42.26 \mu \mathrm{m} \pm 4.39 ; p<0.01)$, EIF $(36.00$ $\mu \mathrm{m} \pm 4.15 ; p<0.01)$, and EIE $(41.86 \mu \mathrm{m} \pm 4.95 ; p<0.01)$ groups compared to the EC $(51.37 \mu \mathrm{m} \pm 3.86)$ group. The data showed that exercise was able to restore muscle trophism in the adult groups; however, none of the protocols has succeeded in aged rats. Conclusion: Immobilization in the shortened position induced muscle atrophy and physical exercise was effective in restoring muscular trophism only in adult animals. Level of Evidence l; Therapeutic studies Investigating the Results of Treatment.
\end{abstract}

Keywords: Muscle, skeletal; Immobilization; Physical exercise; Age factors.

\section{RESUMO}

Introdução: A imobilização éuma técnica de tratamento utilizada frequentemente para redução de dor e prevenção do agravamento da lesão. Entretanto, promove efeitos nocivos no tecido músculo-esquelético, resultando em perda acentuada de função muscular, que pode ser agravada em idosos. O exercício físico constitui intervenção importante para atenuar esses efeitos nocivos. Objetivo: Analisar possíveis alterações morfométricas no músculo gastrocnêmio de ratos após imobilização e remobilização com exercício físico. Métodos: Cinquenta e seis ratos divididos em grupo adulto (A) e grupo idoso (E) e subdivididos em controles adultos e idosos (AC E EC), imobilizado (Al e EI), remobilizado livre (AIF e EIF) e remobilizado por meio de exercício físico (AIE e EIE). Os membros traseiros foram imobilizados com o músculo gastrocnêmio em posição de encurtamento por um período de sete dias, exceto no grupo controle. O protocolo de exercícios foi composto por cinco sessões de natação uma vez por dia (25 minutos/sessão). Os animais foram submetidos à eutanásia por administração de cloridrato de cetamina em dose elevada e cloridrato de xilazina, seguida da coleta da amostra e preparação das lâminas com hematoxilina e eosina. Foram feitas as medidas do menor diâmetro de 120 fibras musculares de cada animal com o software NIS-Elements D3.0 - SP7- Nikon ${ }^{\circledR}$ instruments Inc. ${ }^{\circledR}, N Y$, EUA. Resultados: Houve redução significante na média do diâmetro das fibras nos grupos Al $(38,43 \mu m \pm 4,20 ; p=0,01)$ e AIF $(36,97 \mu m \pm 3,41 ; p<0,01)$ com relação ao grupo AC $(45,39 \mu m \pm 3,41)$ e dos grupos EI $(42,26 \mu m \pm 4,39 ; p<0,01)$, EIF $(36,00 \mu m \pm 4,15 ; p<0,01)$ e EIE $(41,86 \mu m \pm 4,95 ; p<$ $0,01)$ com relação ao grupo EC $(51,37 \mu m \pm 3,86)$. Os dados mostraram que o exercício foi capaz de restaurar o trofismo muscular nos grupos adultos; entretanto, nenhum dos protocolos teve sucesso nos ratos idosos. Conclusão: A imobilização em posição de encurtamento induziu à a trofia muscular e o exercício físico foi eficaz para restabelecero trofismo muscular apenas nos animais adultos. Nível de Evidência l; Estudos terapêuticos - Investigação dos resultados do tratamento.

Descritores: Músculo esquelético; Imobilização; Exercício físico; Fatores etários.

\section{RESUMEN}

Introducción: La inmovilización es una técnica de tratamiento utilizada frecuentemente para reducir el dolor y prevenir el agravamiento de la lesión. Sin embargo, promueve efectos nocivos en el tejido músculo-esquelético, resultando en una pérdida acentuada de función muscular y puede agravarse en ancianos. El ejercicio físico constituye una intervención importante para atenuar estos efectos nocivos. Objetivo: Analizar posibles cambios morfométricos en el músculo gastrocnemio de ratas después de la inmovilización y removilización con ejercicio físico. 
Métodos: Cincuenta y seis ratas divididas en grupo adulto (A) y mayores (E) y subdividas en controles adultos y mayores (ACyEC), inmovilizado (Aly EI), removilizado libre (AIFy EIF) y removilizados con ejercicio físico (AIEy EIE). Las extremidades traseras de los animales fueron inmovilizados con el músculo gastrocnemio en posición de acortamiento por un período de siete días, excepto en el grupo control. El protocolo de ejercicios se compuso de cinco sesiones de natación una vez el día (25 minutos/sesión). Los animales fueron sometidos a la eutanasia por administración de clorhidrato de ketamina en dosis elevada y clorhidrato de xilazina, seguida de la recolección de la muestra y preparación de las láminas con hematoxilina y eosina. Se realizaron las medidas del menor diámetro de 120 fibras musculares en cada animal con el programa NIS-Elements D3.0 - SP7- Nikon ${ }^{\circledR}$ Instruments Inc. ${ }^{\circledR}, N Y$, EE.UU. Resultados: Hubo una reducción significativa en la media del diámetro de las fibras en los grupos $\mathrm{Al}(38,43 \mu \mathrm{m} \pm 4,20 ; p=0,01)$ y $\operatorname{AIF}(36,97 \mu \mathrm{m} \pm 3,41 ; p<0,01)$ en comparación con el grupo $A C(45,39$ $\mu m \pm 3,41)$ y de los grupos EI $(42,26 \mu m \pm 4,39 ; p<0,01)$, EIF $(36,00 \mu m \pm 4,15 ; p<0,01)$ y EIE $(41,86 \mu m \pm 4,95 ; p<0,01)$ con relación al grupo $E C(51,37 \mu m \pm 3,86)$. Los datos mostraron que el ejercicio fue capaz de restaurar el trofismo muscular en los grupos adultos; sin embargo, ninguno de los protocolos tuvo éxito en las ratas mayores. Conclusión: La inmovilización en posición de acortamiento indujo a la atrofia muscular y el ejercicio físico fue eficaz para restablecer el trofismo sólo en los animales adultos. Nivel de Evidencia l; Estudios Terapéuticos - Investigación de los resultados del Tratamento.

Descriptores: Músculo esquelético; Inmovilización; Ejercicio físico; Factores de edad.

\section{INTRODUCTION}

In orthopedics, joint immobilization is a frequently used treatment technique for the reduction of pain and prevention of worsening injury. However the state of inactivity promotes harmful effects on skeletal muscle tissue, reducing its mass, size, and the number of myofibers, factors which result in great loss of muscle function, ${ }^{1,2}$ and these effects can be even more harmful older individuals.,4

When submitted to muscular inactivity, muscle tissue increases the synthesis of reactive oxygen species (ROS) that reduce protein synthesis by inhibiting Akt or mTORC1, and induce muscle proteolysis, resulting in rapid atrophy of the muscle tissue and great damage to its function. ${ }^{5}$

The elderly individual, when subjected to immobilization, presents a potentiation of adverse effects due to the natural loss of muscle mass resulting from the aging process. It is estimated that elderly individuals lose about $1 \%$ of their muscle mass every year, so the recovery of muscle mass in these individuals is extremely important for maintaining the quality of life of the elderly, as well as preventing falls, which are very common in this population. 2,6,7

After immobilization there is the need to restore muscle mass lost during the period of inactivity. In this sense physical exercise presents itself as an important intervention as it promotes increased muscle mass, improving the range of motion.?

The increase in muscle mass occurs mainly by an increase in the cross section of skeletal muscle tissue, which occurs through the plasticity of muscle tissue, stimulating alterations in its microscopic structure, resulting in muscle hypertrophy. ${ }^{8}$ Exercise promotes stimulus opposite to the immobilization by stimulating protein synthesis and reducing proteolysis?

However the process of atrophy due to inactivity, and the recovery of muscle after atrophy do not occur in the same way in elderly and adult animals, with a slower process in the elderly than in adults.? Thus the present study aims to evaluate the muscle tissue of adult and elderly rats subjected to inactivity by means of joint immobilization, using exercise as a way to restore muscle mass lost during the immobilization period, with the hypothesis that exercise would restore lost muscle mass, and allow a quick recovery for both adult and elderly animals.

\section{METHODS}

In total, 56 male Wistar rats were used (Rattus norvegicus) from the Central Animal Laboratory at the Universidade Estadual Paulista (UNESP) - Botucatu, SP, and housed in the bioterium of the Histology and Histochemistry Laboratory of Presidente Prudente (FCT/UNESP). The animals were kept in collective cages with four animals each, under controlled conditions of temperature $\left(22 \pm 2^{\circ} \mathrm{C}\right)$ and humidity $(50 \pm 10 \%)$ and a light/dark cycle of 12 hours (7-19h), with feed and water ad libitum. All procedures adopted were approved by the Ethics Committee on Animal Use (CEUA) of the Faculty of Science and Technology, Presidente Prudente (FCT / UNESP) under No. 05/2010.

The animals were divided into two groups according to age; Group A, aged five months (adult) and Group El, aged 15 months (elderly). The animals were randomly subdivided into four experimental groups:

- Adult control (AC, $n=7$ ) and elderly control ( $E C, n=7)$ : Animals that remained in the vivarium during the trial period and were euthanized in a paired manner with the remobilized groups.

- Adult immobilized ( $\mathrm{Al}, \mathrm{n}=7$ ) and Elderly immobilized ( $E I, n=7)$ : Animals that were submitted to plaster cast immobilization and euthanized shortly after its removal.

- Adult remobilized free (AIF, $n=7$ ) and Elderly remobilized free (EIF, $n=7)$ : Animals that were submitted to plaster cast immobilization followed by free remobilization, being subsequently euthanized.

- Adult remobilized through physical exercise (AIE, $n=7$ ) and Elderly remobilized through physical exercise $(E I E, n=7)$ : Animals that were submitted to plaster cast immobilization followed by two days of free remobilization and swimming physical exercise for five days, being subsequently euthanized.

The animals were anesthetized with an association of ketamine (70 mg/kg) and xylazine $(15 \mathrm{mg} / \mathrm{kg})$, intraperitoneally. ${ }^{9}$ Next, the ankles of the animals were wrapped with tubular mesh, and quick-drying plaster bandage was used for bilateral hindlimb immobilization, from the pelvis to the ankle, maintaining extension of the pelvis, hip, knee, and ankle plantarflexion. The animals remained immobilized for seven consecutive days ${ }^{3}$ and were kept in individual cages with free access to food and water. The plaster was replaced when necessary, following the same procedure.

After removal of the immobilization, the animals from AIF and EIF groups were placed in collective cages for free remobilization, remaining in the vivarium for seven days, before being euthanized. The animals of groups AIE and EIE were also subjected to the same procedure, but for a period of two days, before the application of the physical exercise protocol.

Prior to the application of the plaster cast immobilization technique in the AIE and EIE groups, the animals underwent a process of adaptation to the liquid medium. The adaptation took place in a cylindrical tank with a 
smooth surface, measuring $120 \mathrm{~cm}$ diameter by $75 \mathrm{~cm}$ high, with a $10 \mathrm{~cm}$ water level and water temperature maintained at $31 \pm 1^{\circ} \mathrm{C}$. The animals remained in this tank for 15 minutes/day for 10 consecutive days. ${ }^{3}$ The purpose of the adaptation was to reduce the stress of the animal, without, however, promoting physiological adaptations resulting from physical exercise.

After two days of free remobilization, the animals of the subgroups AIE and EIE were submitted to five daily sessions of physical exercise in the water, using the same cylindrical tank as the adaptation, with the water at a depth of $70 \mathrm{~cm}$, for 25 minutes. The exercise was performed without added overload.

The animals were euthanized by means of an overdose of ketamine hydrochloride and xylazine, intraperitoneally, ${ }^{9}$ following the ethical principles in animal research. The left gastrocnemius muscle of each animal was removed and cut, maintaining the greatest portion of the muscle spindle for subsequent fixing by the Unfixed Tissue Freezing Method. ${ }^{9}$ The samples were stored in a nitrogen canister at $-180^{\circ} \mathrm{C}$ for subsequent histological analysis.

The histological slides were prepared through transversal cuts of $5 \mu \mathrm{m}$ in a microtome cryostat, Microm - HM 505E, and stained according to the hematoxylin and eosin method (HE). ${ }^{9}$ Subsequently, three fields of each muscle sample were captured using the optical microscope Nikon 50i with a 20x objective.

Next, the minimum diameter of 120 muscle fibers from each animal was measured using the software NIS-Elements D3.0 - Nikon ${ }^{\circledR}$ instruments Inc., NY, USA. ${ }^{8}$

\section{Statistical analysis}

The data obtained were analyzed using SPSS 17.0 statistical software for Windows, the Shapiro-Wilk test being applied. For comparison between groups, analysis of variance (one-way ANOVA) was used, followed by Tukey's post-test for comparison between subgroups within each group ( $A$ and $E$ ), considering a 5\% significance level.

\section{RESULTS}

According to the results of the analysis of variance (Figure 1), it was found smaller value of smallest diameter in Al group, compared to AC $(p=0.01)$. In elderly animals the EC group showed higher values of smaller diameter compared to EI $(p<0,01)$, EIF $(p<0,01)$ and EIE groups $(p<0,01)$.

\section{DISCUSSION}

The present study demonstrated that after seven days of immobilization, muscle disuse promoted significant atrophy of muscle tissue, both in adult (five months) and elderly animals (15 months), ${ }^{3,10}$ and that exercise was able to reverse this harmful effect in a seven day exercise intervention in adult animals, however in the elderly animals, seven days of exercise were not enough to reverse the process of muscle atrophy.

The atrophy process induced by immobilization was verified in the present study by the reduction in muscle cell diameter in both the adult and elderly animals; the loss of muscle mass in the elderly is of particular concern, as it represents an important risk factor for falls and fractures..$^{11}$ In addition to damaging the muscle function, reduction in the transverse section of the muscle after immobilization can further demonstrate an increase in cellular apoptosis signaling in the muscle. ${ }^{12}$

Muscle disuse, besides promoting atrophy of muscle cells, also generates a state of cell catabolism that occurs due to alterations in the cell metabolism, damaging mitochondrial function and increasing production of reactive oxygen species and reactive nitrogen species, among other factors. ${ }^{1,5,13}$ One week of immobilization has also been demonstrated as a major activator of atrofin-1 and MuRF-1 gene expression, two muscle-specific binders of E3-ubiquitin ligase, which regulates proteolysis. ${ }^{1,14}$

Even after seven days of free remobilization there was no significant increase in the cross-sectional area of muscle cells, either in the adult or elderly animals (AIF and EIF groups). This result confirms previous studies, both in animals and humans. ${ }^{12,15,16}$ A potential mechanism may be related to myonuclear apoptosis, which occurs during immobilization and remains during remobilization, ${ }^{6}$ moreover, the mRNA expression of atroginna- 1 and MuRF1, and proteasome activity, elements that promote proteolysis, present a return to basal levels only after seven days of remobilization. ${ }^{15}$

Although seven days of free movement in the cage were not enough to reverse the harmful effects of immobilization, exercise was able, in the adult animal group, to restore the cross-sectional area of muscle tissue to values close to those of the control group. Physical exercise increases glucose uptake and stimulates hypertrophy in muscle tissue. The increased glucose uptake occurs in response to the contractile muscle stimulation, promoting improved nutritional support for muscle cells. ${ }^{4,8,17}$ In addition, exercise promotes a reduction in the expression of proteolytic genes after $12 \mathrm{hs}$ of recovery, and stimulates muscle hypertrophy, principally through activation of the mTOR pathway. ${ }^{17}$

The animals in the elderly groups did not present an improved muscle atrophy framework, even after performing exercise (EIE), differing from the adult animals (AIE). Elderly animals present a natural loss of muscle due to sarcopenia, and this situation is aggravated by the state of proteolysis promoted by immobilization. Furthermore, immobilization
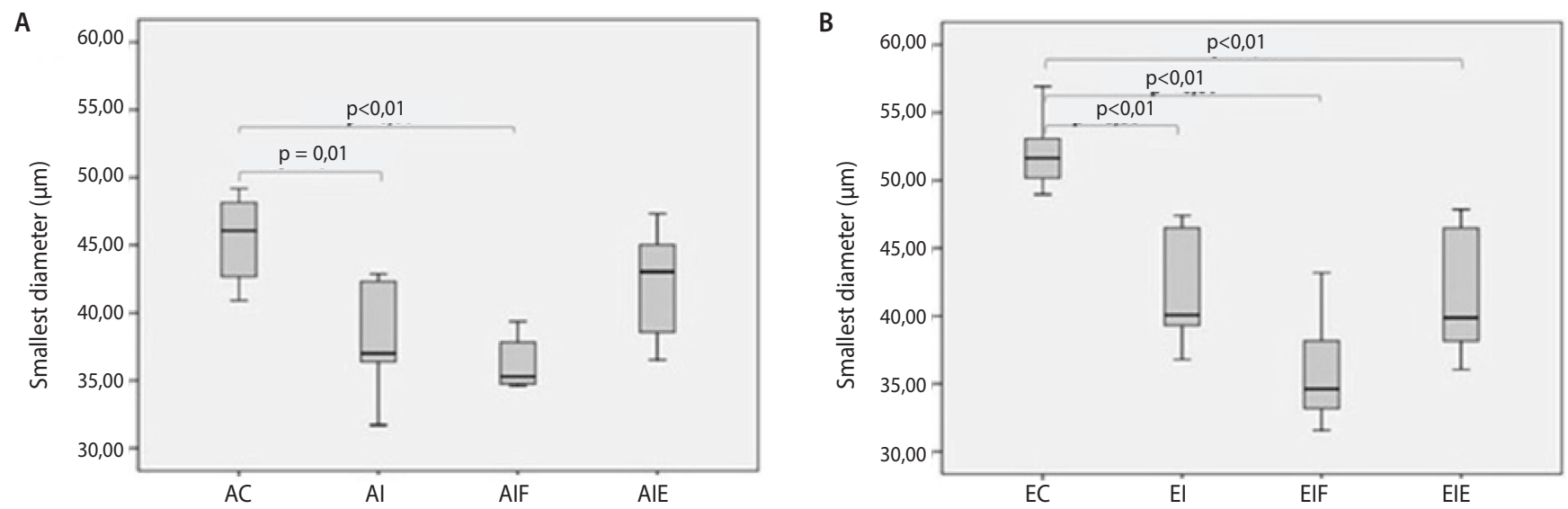

Figure 1. Measures of smallest muscle fiber diameter of the left gastrocnemius. A) Adult groups and B) Elderly groups. 
promotes an "anabolic resistance" state during remobilization in older animals, which may be due to the state of inflammation promoted by immobilization, causing impairment in the protein synthesis pathway, accelerating the development of sarcopenia. 12,18,19

The present study presents little explored results with respect to the immobilization process in older animals, and demonstrates results that may help to clarify and improve intervention in the remobilization process after muscle disuse, either by immobilization or bed rest, among other causes, possibly improving the quality of life of the elderly population.

Regarding the limitations of this research, we should mention that the different models of exercise as well as more immobilization period could contribute to the present research, besides analysis such as quantification of atrogin-1 and MuRF1, as well as mTOR; which could provide more information about the processes of atrophy and hypertrophy involved in immobilization.

\section{CONCLUSION}

It is concluded that immobilization promoted a reduction in cross-sectional area in the muscles of all animals, and that the exercise protocol was able to restore muscle trophism in adult animals, however was not enough to reverse the atrophy in elderly animals.

All authors declare no potential conflict of interest related to this article.

AUTHORS' CONTRIBUTIONS: Each author made significant individual contributions to this manuscript. TEK (0000-0002-9423-9965)*: surgery, writing of the article, intellectual concept of the article and preparation of the entire research project; AYW (0000-0002-8713-9456)* writing of the article, intellectual concept of the article and preparation of the entire research project; FYK (0000-0002-2517-4547)*: intellectual concept of the article, statistical analysis and corrections to the entire research project, and the final article; GATO (0000-0002-0133-960X)*: writing, analysis of data and revision of article; RCC (0000-0002-4167-6790)*: surgery, revision of the final text; TAG (0000-0003-1031038-X)*: analysis of the slides, statistics; RCTC (0000-0003-3465-4275)*: review of the project and final text; JCSCF (0000-0002-5665-5837)*: intellectual concept of the article and preparation of the whole research project, analysis of the slides and correction of the final text. ${ }^{*}$ ORCID (Open Researcher and Contributor ID).

\section{REFERENCES}

1. Kang C, Yeo D, Ji LL. Muscle immobilization activates mitophagy and disrupts mitochondrial dynamics in mice. Acta Physiol (Oxf). 2016;218(3):188-97.

2. Dideriksen $K$, Boesen AP, Kristiansen JF, Magnusson SP, Schjerling P, Holm L, et al. Skeletal muscle adaptation to immobilization and subsequent retraining in elderly men: no effect of anti-inflammatory medication. Exp Gerontol. 2016;82:8-18.

3. Kodama FY, Camargo RC, Job AE, Ozaki GA, Koike TE, Camargo Filho JC. Muscle mechanical properties of adult and older rats submitted to exercise after immobilization. Acta Ortop Bras. 2012;20(4):218-22.

4. Yoshihara T, Machida S, Kurosaka Y, Kakigi R, Sugiura T, Naito H. Immobilization induces nuclear accumulation of HDAC4 in rat skeletal muscle. J Physiol Sci. 2016;66(4):337-43.

5. Powers SK, Morton AB, Ahn B, Smuder AJ. Redox control of skeletal muscle atrophy. Free Radic Biol Med. February 2016:1-10.

6. Kelleher AR, Pereira SL, Jefferson LS, Kimball SR. REDD2 expression in rat skeletal muscle correlates with nutrient-induced activation of $\mathrm{mTORC1}$ : responses to aging, immobilization, and remobilization. Am J Physiol Endocrinol Metab. 2015;308(2):E122-9..

7. White JR, Confides AL, Moore-Reed S, Hoch JM, Dupont-Versteegden EE. Regrowth after skeletal muscle atrophy is impaired in aged rats, despite similar responses in signaling pathways. Exp Gerontol. 2015;64:17-32

8. Castoldi RC, Camargo RC, Magalhães AJ, Ozaki, GAT, Kodama FY, Oikawa SM, et al. Concurrent training effect on muscle fibers in Wistar rats. Motr Rev Educ Física. 2013;19(4):717-23.

9. Camargo Filho JC, Garcia BC, Kodama FY, Bonfim MR, Vanderlei LC, Ramos EM, et al. Effects of aerobic exercise on the skeletal muscle of rats exposed to cigarette smoke. Rev Bras Med do Esporte. 2011;17(6):416-9.

10. Lafoux A, Baudry C, Bonhomme C, Ruyet P Le, Huchet C. Soluble milk protein supplementation with moderate physical activity improves locomotion function in aging rats. PLoS One. 2016;11(12):1-20.
11. Mithal A, Bonjour J-P, Boonen S, Burckhardt P, Degens H, El Hajj Fuleihan G, et al. Impact of nutrition on muscle mass, strength, and performance in older adults. Osteoporos Int. 2013;24(5):1555-66.

12. Hao Y, Jackson JR, Wang Y, Edens N, Pereira SL, Alway SE. $\beta$-Hydroxy- $\beta$-methylbutyrate reduces myonuclear apoptosis during recovery from hind limb suspension-induced muscle fiber atrophy in aged rats. Am J Physiol Regul Integr Comp Physiol. 2011;301(3):R701-15.

13. Powers SK, Radak Z, Ji LL. Exercise-induced oxidative stress: past, present and future. J Physiol. 2016;594(18):5081-92.

14. Kang C, Goodman CA, Hornberger TA, Ji LL. PGC-1a overexpression by in vivo transfection attenuates mitochondrial deterioration of skeletal muscle caused by immobilization. FASEB J. 2015;29(10):4092-106.

15. Lang CH, Pruznak A, Navaratnarajah M, Rankine KA, Deiter G, Magne H, et al. Chronic a-hydroxyisocaproic acid treatment improves muscle recovery after immobilization-induced atrophy. Am J Physiol Endocrinol Metab. 2013;305(3):E416-28.

16. Kazi AA, Hong-Brown L, Lang SM, Lang CH. Deptor knockdown enhances mTOR Activity and protein synthesis in myocytes and ameliorates disuse muscle atrophy. Mol Med. 2011;17(9-10):925-36.

17. Egan B, Zierath JR. Exercise metabolism and the molecular regulation of skeletal muscle adaptation. Cell Metab. 2013;17(2):162-84.

18. Magne H, Savary-Auzeloux I, Migné C, Peyron MA, Combaret L, Rémond D, et al. Contrarily to whey and high protein diets, dietary free leucine supplementation cannot reverse the lack of recovery of muscle mass after prolonged immobilization during ageing. J Physiol. 2012;590(8):2035-49.

19. Magne H, Savary-Auzeloux I, Migné C, Peyron M-A, Combaret L, Rémond D, et al. Unilateral hindlimb casting induced a delayed generalized muscle atrophy during rehabilitation that is prevented by a whey or a high protein diet but not a free leucine-enriched diet. PLoS One. 2013;8(8):e70130. 